\title{
The Role Orientation of Information Technology Teachers Against the Background of Maker Education
}

\author{
Feiya Chen ${ }^{1, a}$, Zhi Zhang ${ }^{2, b}$ \\ ${ }^{1}$ School of Hunan University, Changsha 410000, China; \\ ${ }^{2}$ School of Hunan University, Changsha 410000, China. \\ a383390283@qq.com, b632027503@qq.com.
}

Keywords: Maker Education, Information Technology, The Role of Teachers.

\begin{abstract}
The rise of the movement of maker has promoted the development of the society, and has also affected the education sector, and many scholars and educators have advocated the application of the concept of maker to the actual teaching to improve the teaching situation. In this process, the role of teachers is particularly important. Based on the concept of maker education and the characteristics of information technology courses, this paper discusses the role of information technology teachers from the perspective of teachers themselves and teacher-student relationship.
\end{abstract}

\section{Introduction}

The comprehensive and rapid development of information technology and Internet technology has promoted the development of education to some extent. Especially in recent years, maker education that emerge with the rise of the maker movement has aroused a strong response in the education sector, many scholars have advocated applying the concept of Maker to the field of education. As a practical and comprehensive subject, information technology can be combined with the maker education and educating students to help them explore and practice better. At present, there are many scholars have discussed how to carry out maker education in the course of information technology .For example, the article titled Innovation Exploration and Practice of Information Technology Teaching in Middle Schools in the Context of Makers Education that written by Zhang Xiaodong, the article titled Elementary School information technology teaching practice in the Context of Makers Education that writtten by Wang Wei and the article titled How to carry out maker education in junior middle school for information technology and so on, the development of education is inseparable from the cooperation of teachers, so it is necessary to explore the role of information technology teachers in the classroom.

\section{The Overview of Maker Education}

\subsection{What is Maker Education.}

Maker is the people who are passionate about design, willing to practice and share, and strive to transform all kinds of ideas into reality, the core elements of the spirit of maker are innovation, practice and sharing [1]. Maker education is the new product that applying the idea of maker to the field of educational practice. It is a new education model with the goal of cultivating compound innovative talents that integrate information technology, adhering to the educational concept of open innovation, explore the experience, and the educational concept, and take the approach of Learning by Creating [2]. The purpose of launching maker education is to make students continuously learn the knowledge of various disciplines and use them in the process of creating. This is a process of using their own creativity to solve problems continuously.

\subsection{The Characteristics of Maker Education.}

Maker education is a product of the rapid development of the Internet and information technology. It aims to cultivate complex innovative talents. Its salient features are mainly reflected in three aspects. The first is learning by doing. Students are no longer confined to teachers and books in maker 
education. They can boldly carry out creative design and operations, in the process of creation, recognize themselves, learning knowledge and accumulate experience; The second is collaborative learning, students need to work under the guidance of teachers in group cooperation. During the process of cooperation, the team members actively ask questions and communicate with each other. In this way, they can not only make progress together but also enhance the awareness of cooperation; The final is the interdisciplinary integration of knowledge and resources, students need to think in different contexts in maker education, so they must build a comprehensive knowledge system by collecting information across a variety of disciplines and resources to improve their ability to use multi-disciplinary knowledge to solve problems [3].

\section{The Characteristics of Information Technology Curriculum}

\subsection{Flexible}

Traditional courses are conducted under the constraints of unified progress, unified requirements, and unified content. This learning process is very rigid. Different from traditional courses, information technology curriculum has not yet formed a stable and unified knowledge system. So, it is flexible no matter in content or teaching progress. Information technology teachers can choose the appropriate content according to the learning situation of the class and adjust the teaching schedule reasonably. What the teachers should do is to transform the passive learning into active learning, and continuously discover new skills of the students so that the students can continuously grow. This is a high demand for information technology teachers in terms of knowledge and teaching ability. Therefore, information technology teachers must not only know what to teach, but also how to teach.

\subsection{Integration}

Information technology is a highly integrated course that based on practice, focusing on innovation, and integrating science and technology with humanities [4]. It involves a large number of marginal disciplines and basic sciences, so its content cannot exist separately from other disciplines. The use of information technology can only be learned when using information technology tools to learn the content of other disciplines. Moreover, the teaching goal of the information technology curriculum in primary and secondary schools is to cultivate students' innovative spirit and practical ability. On this basis, they also emphasize the comprehensiveness of the content. These are all in line with the concept of maker education, so it is very necessary and feasible to integrated the concept of maker education into the teaching of information technology courses.

\subsection{Practicality}

In order to improve students' ability to apply information technology to solve practical problems, Information technology advocates students to use information technology to practice and create. In information technology courses, students do not listen as much as they do in other subjects. instead, they work under the guidance of a teacher and combine life practices. During operation, they complete the organic combination of theoretical knowledge and practice and achieve the effect of learning to use. This feature could cultivate students' innovative spirit and practical ability better if combined with the "learning by doing" feature of maker education.

\section{The Role Orientation of Information Technology Teachers in the Background of Maker Education}

\subsection{The Learners and Users of New Concept}

The most important thing to launch maker education in information technology courses is to enable students to participate actively. Therefore, information technology teachers must first learn the educational philosophy of open innovation, explore the experience. To make students can not only acquire knowledge through hands-on practice in the classroom, but also find their use in life, information technology teachers should highlight the knowledge and skills closely related to daily learning and life in content. In the teaching process, according to the student's age characteristics using maker videos or physical displays to motivate students' interest in learning is a good idea; Last, 
in teaching methods, what teachers need to do is aside the identity of their own lecturers and give the class to the students to the maximum extent, so that students could create and practice based on their own interests. In short, information technology teachers must first break the original concepts, learn, understand and apply the concept of maker education, and incorporate some novel and interesting life phenomena into the class, and encourage students actively participate in the course and demonstrate their own thoughts in the process of discussion and communication if they want to develop maker education better.

\subsection{The Designers and Developers of Curriculum}

Information technology courses are more flexible in terms of content and teaching progress. therefore, in order to carry out maker education in information technology courses, information technology teachers must formulate reasonable teaching content according to the specific conditions of schools and students. They should naturally integrate the maker education into the information technology classroom from the perspective of curriculum design and development. Teachers should analyze and preliminarily design the teaching content according to the teaching objectives and design the curriculum suitable for the students by observing the students instead of the same contents presented in any class as any other class. Since the students in each class are different, teachers can design and develop corresponding information technology courses according to the specific conditions of each class of students, if the conditions permit. In addition, information technology teachers should not only consider the information technology course in the curriculum design, but also combine the relevant knowledge of other disciplines so that students can experience the connection between various disciplines in the process of learning, and gradually develop student information literacy and the ability to use multi-disciplinary knowledge to solve problems. This is a good idea to promoting the launch of maker education in information technology courses.

\subsection{The Guider and Motivator of the Creative Process}

The purpose of carrying out student education in information technology courses is to cultivate students' innovative spirit and hands-on practical ability. Although teachers are required to change the role of traditional imparters and give full play to the main role of students, teachers' guidance and encourage are still indispensable throughout the entire process. When students lack creativity and do not know how to start, teachers should guide them through specific examples to stimulate their inspiration. When students encounter problems in the creative process, teachers should not directly give answers, but to encourage them to find some similar cases through information technology means, and then communicate with peers to try to solve problems by themselves; when they can solve some problems in the exchange and discussion or make progress in the creation, teachers should affirm their actions and raise them at a higher level. The creative requirements make students feel that they are doing well and can do better. When necessary, information technology teachers can also serve as helpers in the student's creative process to help them discover deficiencies in their creation and correct them in a timely manner.

\subsection{The Appraiser of Works}

Evaluation is an indispensable part of the education and teaching activities. In the information technology course where carry out maker education, teachers must not only evaluate students' learning process and learning results, but also evaluate the final works they present. If the work is done on its own, and the teacher evaluates the work objectively, it also evaluates the creative consciousness in the student's creative process as well as the information literacy that is demonstrated in solving the problems encountered; if the creation is based on group work, evaluations should be made in units of teams, and individual performance cannot be ranked as an overall achievement [5]. When conducting group evaluations, in addition to considering the innovative awareness and information literacy of team members, we must also focus on evaluating the team members' sense of cooperation in the process of cooperation so that students fully realize the benefits that solidarity and cooperation can bring for themselves. This mode of evaluation will promote collaborative learning. 


\section{Summary}

To sum up, in the context of maker education, in the process of information technology courses, teachers need to combine their own practical needs with the requirements of the maker education, actively change their concepts and roles, and try to be the learners and users of new concept, designers and developers of curriculum, guiders and motivators of creation process, and appraisers of works. However, such role positioning is not static, teachers need to continue to adjust and improve according to their actual teaching situation, to further give play to the vanguard role of the maker education and promote the better development of maker education. Therefore, the positioning of information technology teachers under the background of maker education is a problem worthy of long-term discussion. This requires not only the teachers' own efforts, but also the cooperation of society, schools, and parents.

\section{References}

[1]. Chris Anderson. Maker: New Industrial Revolution [M]. CITIC Publishing House. 2012.

[2]. Xianmin Yang, Jihong Li. The Value Potential and Controversy of Makers' Education [J]. Modern Distance Education Research, (2008) NO.11, p.23-34.

[3]. Wei Wang. Talking about the Practice of Information Technology Teaching in Elementary School under Makers Education [J]. Computer teaching and education informatization, (2016) NO.24, p. 109-110.

[4]. Dan Liu:Research on Teaching Design of High School Information Technology Course Based on the Concept of Maker [D].(Master, Jiangsu Normal University, China 2016).p.2-3

[5]. Yijin Liu. Integration of Maker Education and Elementary Science Curriculum [J]. Scientific inquiry, (2018) NO.1, p.23. 